Boletín de la Sociedad Geológica Mexicana

VOLUMEN 65, NÚM. 1, 2013, P. 99-107

\title{
Occurrence of a tylosaurine mosasaur (Mosasauridae; Russellosaurina) from the Turonian of Chihuahua State, Mexico
}

\author{
Abelaid Loera Flores ${ }^{1}$ \\ ${ }^{1}$ Dirección de Minerales Energéticos, Gerencia de Evaluación, Servicio Geológico Mexicano, Calle Industrial 6, Lote 6, Int. 2, Zona \\ Industrial Robinson, C.P. 31074, Chihuahua, Chihuahua, México. \\ *alflores@sgm.gob.mx
}

\begin{abstract}
A new mosasaur specimen was discovered in the Ojinaga Formation (Turonian) in Chihuahua, Mexico. It is described here based on an incomplete, slightly deformed skull. Comparative analysis reveals features from the parafamily Russellosaurinae, especially the genus Tylosaurus. Some features as the "V" shaped skull, well developed rostral process, 12 to 13 dentary and maxillary teeth, shape of premaxilla-maxilla suture, and similar proportions of mandible and quadrate bone are characteristics of Tylosaurus, and are similar to T. proriger and T. nepaeolicus, but the absence of an infrastapedial process indicates it is most closely related to $T$. kansasensis.
\end{abstract}

Keywords: Mosasauridae, Chihuahua, Ojinaga Formation, Tylosaurus.

\section{Resumen}

Un nuevo espécimen de mosasaurio fue descubierto en la Formación Ojinaga (Turoniano), en el estado de Chihuahua, México; aqui se describe con base en un cráneo incompleto, ligeramente deformado. El análisis comparativo revela caracteres pertenecientes a la parafamilia Russellosaurina, en especial al género Tylosaurus. Algunos caracteres como el cráneo en forma de " $V$ ”, proceso rostral bien desarrollado, 12 a 13 dientes maxilares y dentarios, sutura premaxilar-maxilar y proporciones similares de la mandibula

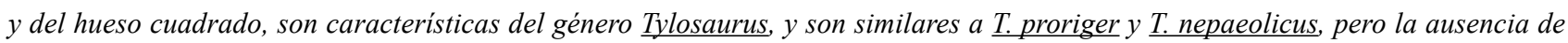
un proceso infrastapedial indica que está más cercanamente relacionado a $\underline{\text {. kansasensis. }}$.

Palabras clave: Mosasauridae, Chihuahua, Formación Ojinaga, Tylosaurus. 


\section{Introduction}

Mosasaurs were a group of marine lizards closely related to monitor lizards or snakes (McDowell and Bogert, 1954; De Braga and Carroll, 1993; Vidal and Hedges, 2004; Lee, 1997; Caldwell, 1999; Lee and Caldwell, 2000). They may have benefited from the extinction of ichthyosaurus and of invading shallow waters during Cenomanian time (Polcyn et al., 1999), and during the Turonian and thereafter, evolved to become the apex predators of the ocean during the remainder of the Late Cretaceous (Russell, 1967; Bell, 1997a). Traditionally, Mosasauridae were thought to be a monophyletic group of hydropedal (paddle-like limbs) mosasaurs that descended from or were closely related to Aigialosauridae (plesiopedal, terrestrial limbs forms). However, the monophyly of Aigialosauridae was questioned by Bell (1997b) and with the discovery of Dallasaurus turneri, a plesiopedal mosasaurine mosasaur (Bell and Polcyn, 2005), the concept of Aigialosaridae lost significant support. Currently, the superfamily Mosasauroidea includes Aigialosauridae, which only contains Aigialosaurus (Bell and Polcyn, 2005; Caldwell et al., 1995) and it is the sister family to Mosasauridae; however, there are no derived characters that define Aigialosauridae, and retention for other than historical purposes is currently not justified. Mosasauridae includes four subfamilies: Halisaurinae, Mosasaurinae, Plioplatecarpinae and Tylosaurinae. The latter two are included in the clade Russellosaurina (Polcyn and Bell, 2005).

The oldest occurrence of derived mosasaurs is in the lower Turonian of Morocco, represented by the russellosaurian Tethysaurus nopcsai (Bardet et al., 2003; Polcyn and Bell, 2005). In Texas, Russellosaurus coheni and Dallasaurus turneri are found in the lower middle Turonian (Bell, 1995; 1997b; Bell and Polcyn, 2005). Other forms are Yaguarasaurus colombianus from the Turonian of Colombia (Páramo, 1994; 2000), and Angolasaurus bocagei and Tylosaurus iembeensis (formerly Mosasaurus iembeensis) from Angola (Antunes, 1964). Recently, a relative derived premaxilla of a mosasaur purportedly similar to Russellosaurus was discovered in the Cenomanian of Russia (Grigor'ev et al., 2009); however, this occurrence is suspect given its highly evolved nature compared with other contemporaneous forms. A few mosasaur specimens have been discovered in Mexico. The first record was Amphekepubis johnsoni, consisting of a partial skeleton from the San Felipe Fm. (Santonian), east of Monterrey (Mehl, 1930); other findings, mainly in the Vallecillo (Nuevo León) area, includes an aigialosaurid (basal mosasaur), which preserves the post-cranial skeleton (Buchy et al., 2005; Buchy, 2007). Campanian-Maastrichtian material is limited to a fragmentary jaw (UANL-FCT-R6) and a skull (UANL-FCT-R4), the cranial anatomy of which was described by Buchy et al. (2007) and is the best preserved cranial remains in Mexico described so far.

This paper reports a tylosaurine mosasaur found in the San Antonio El Bravo area, Ojinaga municipality, in the central-eastern portion of Chihuahua state (Figure 1). It was collected in the middle member of the Ojinaga Formation, during Late Cretaceous coal shale exploration by the Dirección de Evaluación de Minerales Energéticos del Servicio Geológico Mexicano.

\section{Geologic Setting}

The Ojinaga Formation was originally defined as sedimentary rocks deposited on the Aurora Formation by Burrows (1910); Vivar (1925) named this unit as the Ojinaga Group, and the thin, stratified shales on the base was named as the Ojinaga Formation. Wolleben (1966) subdivided the Ojinaga Group into Ojinaga, San Carlos and Picacho formations. The Ojinaga Formation correlates to the Indidura Formation of Coahuila (Petróleos Mexicanos, 1982; Castillo-Madrid, 1982), the Pen and Boquillas formations of the Big Bend region, Texas, the Agua Nueva Formation from northeastern Mexico, and the Eagle Ford (Castillo-Madrid op cit.; Mena-Escobar, 1994) and Austin formations of western Texas in the lower and upper member, respectively (Mena-Escobar op cit.,; Wolleben, 1966). Petróleos Mexicanos (1983) described the Ojinaga Fm. as fissile shale and thin beds of dark gray, clayey mudstone, and yellow colored, medium-grained, calcareous sandstone. According to the section measured by the Servicio Geológico Mexicano (SGM), at the site of the discovery of the specimen (Figure 1), the Ojinaga Fm. thickness is approximately $714 \mathrm{~m}$ (Wolleben, 1965) and consists of a series of interbedded, dark gray shales, marls and thin mudstone with Inoceramus sp. and layers with ferrous concretions. The depositional environments of the Ojinaga Formation were: an open shelf (Petróleos Mexicanos, 1983; McBride and Caffey, 1979; CantúChapa, 1993); a deep, neritic environment with abundant terrigenous input, and deep, closed, restricted ocean water circulation and reducing conditions in marginal lagoons (Mena-Escobar, 1994). The lack of ammonite fossils makes it difficult to establish a reliable stratigraphic control, but other studies of the Ojinaga Fm. indicate that its age ranges from Cenomanian to Maastrichtian (Castillo-Madrid, 1982), Cenomanian to Santonian (Cabrera et al., 1984), late Cenomanian to early Coniacian (Monreal, 1987), and late Cenomanian to Turonian (Cantú-Chapa, 1993).

The paleogeography of the Chihuahua trough is related to the Western Interior Seaway during the Turonian. At that time, a change of the sediment type took place: from shallow water carbonates to marine clastic deposits, all related to the last stages of the Sevier orogeny (Muehlberger, 1992; Haenggi, 2002). Units such as the Ojinaga Formation and the correlatable Indidura Formation (Petróleos Mexicanos, 1982) were deposited in neritic environments of variable depth, depending on former paleogeographic elements upon which sedimentation took place: the Indidura Formation 

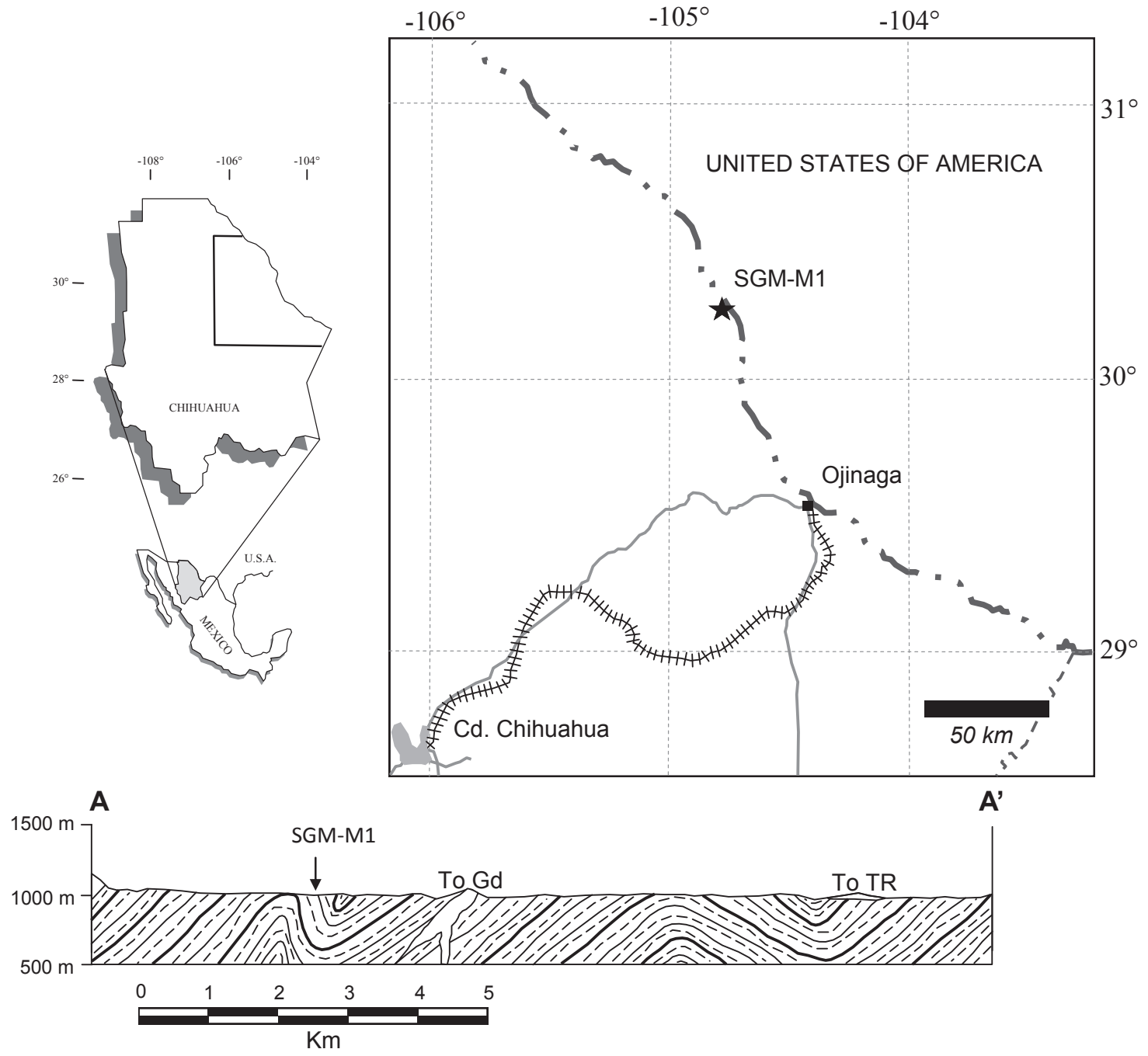

Figure 1. Location of mosasaur fossil SGM-M1, approximately $84 \mathrm{~km}$ northwest of Ojinaga, in the middle member of the Ojinaga Formation (Section A-A'). ToGd, granodiorite; ToTr, rhyolitic tuff.

deposited on the Aldama and on the Coahuila platforms, and the Ojinaga Formation deposited on the eastern limit of the Chihuahua basin, at the very edge of El Diablo platform. Evidence of variable thicknesses from different zones are: Ojinaga área (Ojinaga Fm, 1395m), Rim Rock county (Ojinaga Fm, 714m), Camargo range (Ojinaga Fm, $144 \mathrm{~m}$ ), Pajaritos range (Indidura Fm, 165m), (Wolleben, 1965; Petróleos Mexicanos, 1982; Petróleos Mexicanos, 1983; Haenggi, 2002). According to Sageman and Arthur (1994), and Haenggi (2002), deposition of the Ojinaga Fm. in the area is coeval with a series of clastic wedges of the Western Interior Seaway. Geographically, is located on the southwestern margin and opening to the Western Interior Seaway (Figure 2), which at that time functions as an estuarine mouth with fresh water influx draining to the Tethys province and salted, deep water in opposite direction (Slingerland et al., 1996).

\section{Systematic Paleontology}

Order Squamata Oppel, 1811

Family Mosasauridae Gervais, 1853

Parafamily Russellosaurina Polcyn and Bell, 2005

Subfamily Tylosaurinae Willingston, 1897

Genus Tylosaurus, Marsh, 1872

Material: Holotype (SGM-M1), Nearly complete skull, cranial vault crushed dorsolaterally and filled with clay, partially oxidized with pyrite. The rostrum includes premaxillae, maxillae and both dentarium, slightly deformed (Figures 3a-d). This fossil is housed at the Oficina Regional Chihuahua (ORC) of the Servicio Geológico Mexicano (SGM).

Horizon and Locality: Specimen collected in the middle member of the Ojinaga Formation, San Antonio El Bravo, approximately $84 \mathrm{~km}$ northwest of Ojinaga, 

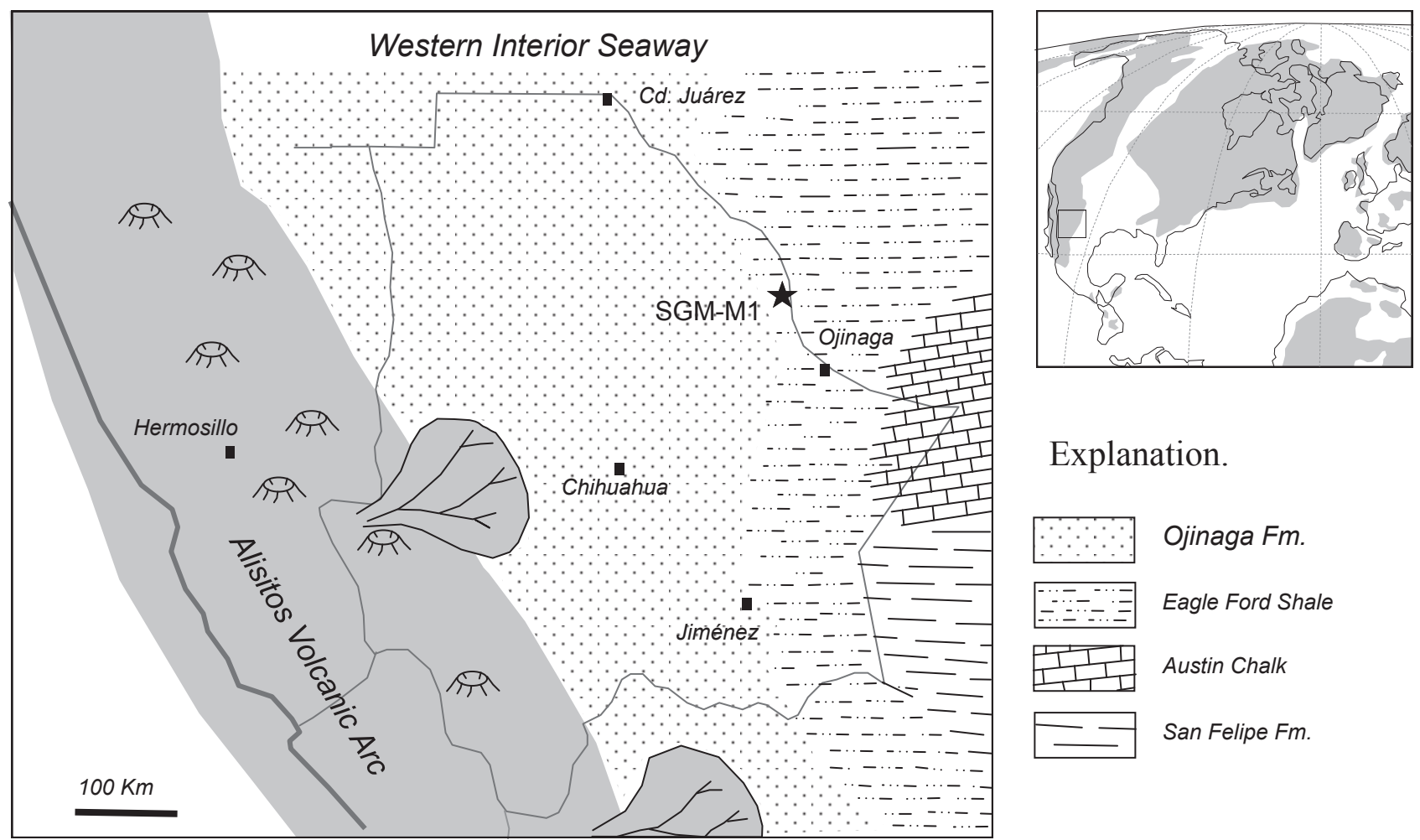

\section{Explanation.}

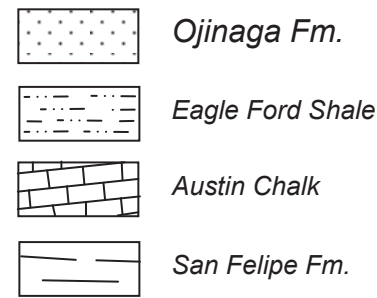

Figure 2. Paleogeography of Chihuahua and Ojinaga during Turonian time (Late Cretaceous). Modified from Mena-Escobar (1994) and Buchy et al. (2007).

Chihuahua (30¹2'45" N, 10446'17” E).

Description: Specimen SGM-M1 has an elongated conical, longirostrine skull with a length of $54.8 \mathrm{~cm}$ from the anterior end of rostral process to the posterior part of cranial cavity. In dorsal view, skull has an elongated "V" shape (Figure 3d). The skull width between orbits is 7.2 $\mathrm{cm}$, stretching towards the rostrum. The rostrum comprises approximately $62 \%$ of the skull length.

Premaxilla: Premaxilla possesses four dental positions, two each side; left teeth are broken on tip, more conical than maxillary teeth; internarial bar is broken $14 \mathrm{~cm}$ posterior of the teeth bearing portion and is triangular in cross-section (Figures $3 \mathrm{~d}$ and $4 \mathrm{~d}$ ). The predental process extends $2 \mathrm{~cm}$ from the first premaxillary tooth, and in lateral view has a slightly conical shape, rounded and projected downward (Figures 4a-b), probably due to crushing. The premaxillamaxilla projects backwards parallel to the rostrum beginning at about the $2^{\text {nd }}$ or $3^{\text {rd }}$ maxillary tooth position.

Maxilla: The left maxilla (Figures $3 \mathrm{a}$ and $4 \mathrm{a}$ ) is long, slender and is fractured at approximately half its length. The suture with the premaxilla is blurred and slightly deformed. Contact with the prefrontal and frontal is broken and eroded; there are 11 teeth distributed in the pattern $1 \mathrm{X}$ 3456 X89 X 11, where " $X$ " represents a missing tooth position, likely in the process of replacement. The right maxilla (Figures $3 b$ and $4 b$ ) is partially crushed by frontal and prefrontal and the contact between elements is irregular due to deformation; the dental replacement pattern is $1 \mathrm{X} 3$ $4 \times 67 \times 910 \times 1213$.
Frontal: Frontal is broad and shield-like (Figures 3d and 4d); there is no indication of midline ridge, but this may be due to erosion. In dorsal view, the lateral margins roughly form a rectangle, wider between orbits with no evidence of postero-lateral projections (alae) anterior to fronto-parietal suture, due to breakage. The anterior margin is damaged and the union between frontal and internarial bar is broken and eroded in the specimen.

Parietal: The visible portion of parietal is badly damaged (figures $3 \mathrm{~d}$ and $4 \mathrm{~d}$ ), but the outline is recognizable, it has a slightly triangular shape anteriorly, but is broken at approximately $8 \mathrm{~cm}$ posterior to fronto-parietal suture. The parietal foramen apparently is located $2 \mathrm{~cm}$ posterior to suture and is diffuse mostly due to weathering.

Prefrontal: Left prefrontal (Figures 3a and 4a) is eroded and filled with a pyritized matrix. The right prefrontal (Figures $3 \mathrm{~b}$ and $4 \mathrm{~b}$ ) is deformed and crushed dorsolaterally, with irregular edges, contact with jugal is blurred and is inferred in the interpretation.

Dentary: The right dentary (Figure $4 b$ ) has a total length of $34 \mathrm{~cm}, 13$ teeth with the following dental formula: X X $345 \times 7891011 \times 13$. The left dentary (Figure 4a) has 12 teeth and a dental formula of: X X 34 X X 7891011 12. Both predentary processes are broken $1 \mathrm{~cm}$ from the first dentary tooth. The dentaries (and anterior left maxilla) presents elongated foramina for the trigeminal nerves, obscured on the posterior portions of the jaws, probably due to preservation. The foramina are approximately half centimeter in length, aligned in a straight line on the central 


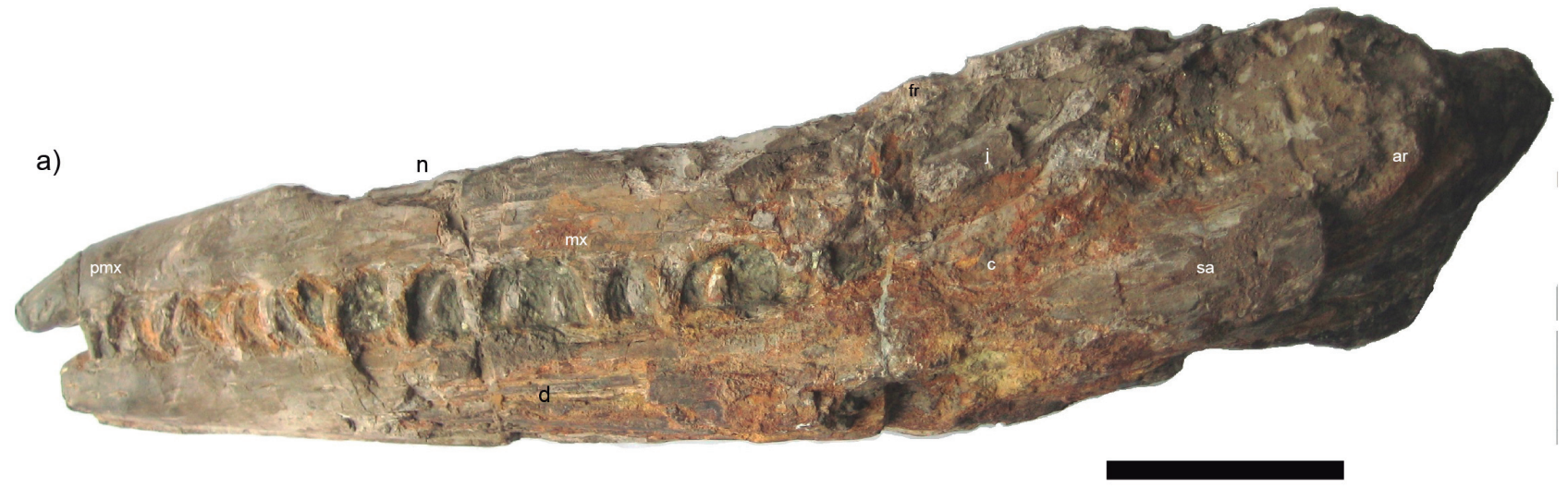

b)
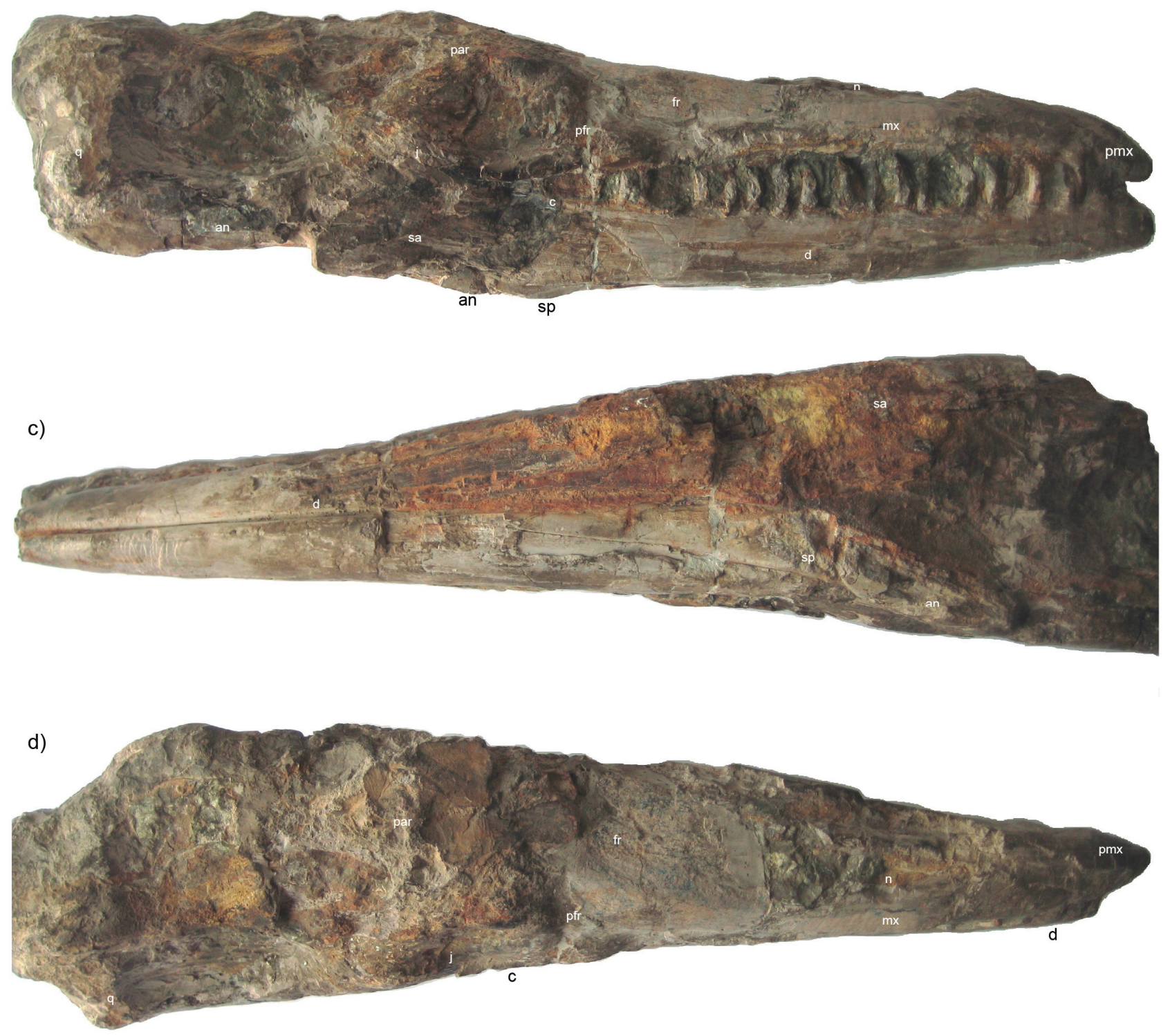

Figure 3. Specimen SGM-M1: a) Left view, b) right view, c) ventral view, d) dorsal view; an. angular; ar. articular; c. coronoid; d. dentary; fr. frontal; j. jugal; mx. maxilla; n. internarial bar; par. parietal; pmx. premaxilla; pfr. Prefrontal; q. quadrate; sa. surangular; sp. splenial. Scale bar equals $10 \mathrm{~cm}$. 


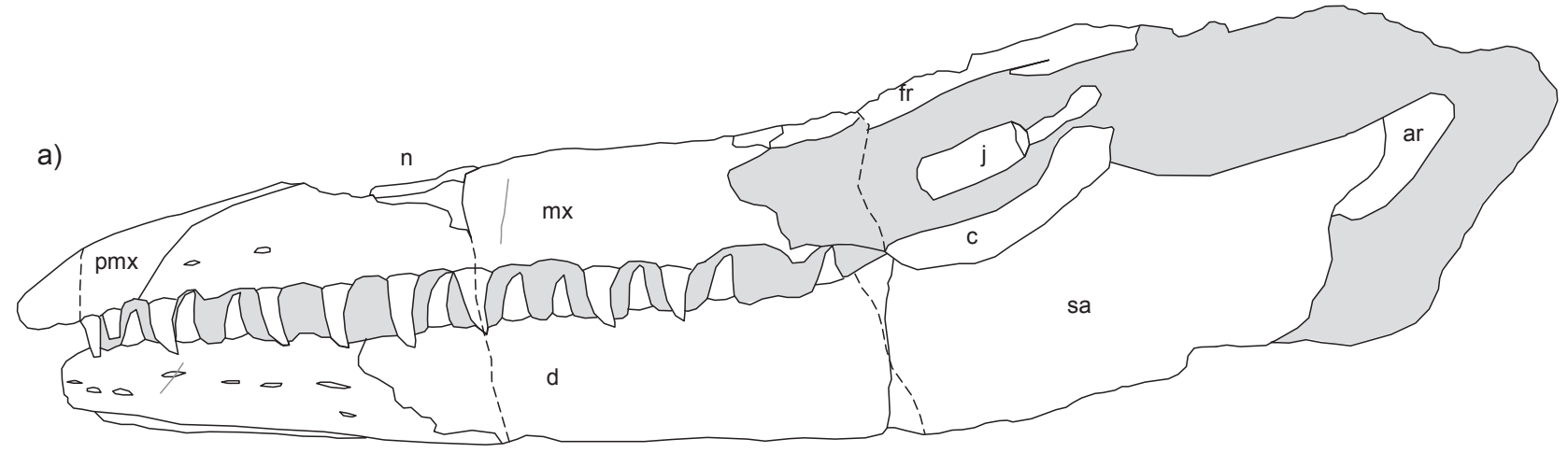

b)
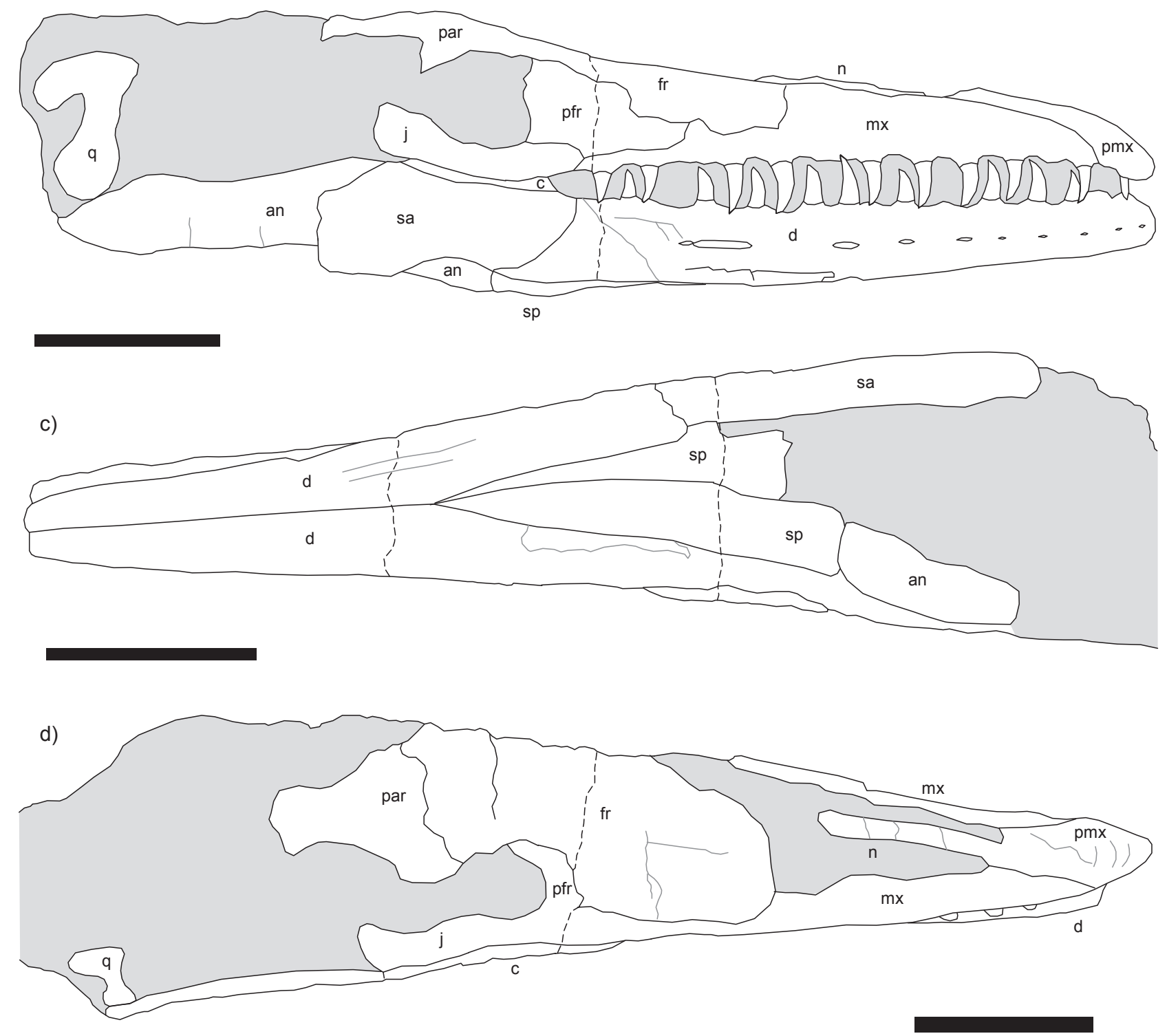

Figure 4. Interpretation of the specimen SGM-M1, a) Left view, b) right view, c) ventral view, d) dorsal view; an. angular; ar. articular; c. coronoid; d. dentary; fr. frontal; j. jugal; mx. maxilla; n. internarial bar; par. parietal; pmx. premaxilla; pfr. prefrontal; q. quadrate; sa. surangular; sp. splenial. Scale bar equals $10 \mathrm{~cm}$. 
portion, with the posterior foramen larger and slightly separated from the rest (Figure 4a). The marginal dentition is homodont with conical teeth slightly curved backwards at the middle and do not have any visible striae or carinae. Most crowns preserve the enamel intact.

Splenial: In ventral view, the ventral portions of both splenials lie in articulation with the dentary (Figure 4c); right splenial overlaps with the left due to preservation (Figures $3 \mathrm{c}$ and $4 \mathrm{c}$ ). The angular-splenial articulation is well defined and straight, but laterally inclines posteriorly (Figure $4 b$ ). In right side view it can be seen only in the posterior portion of the dentary. The left splenial is only visible on ventral view and is broken on its tip (Figure 4c).

Angular: The right splenial-angular articulation inclines posteriorly on lateral view, its posterior half is visible due to surangular missing a half of its length. Left angular is missing (Figures $3 \mathrm{c}$ and $4 \mathrm{c}$ ).

Surangular: The left surangular is complete and robust with a total length of $21 \mathrm{~cm}$ (Figures 3 and 4), but the right is broken at approximately half its length, revealing what appears to be the articular. Judging from the left side, the surangular-articular suture slopes anteroventrally in a relatively tight radius, and then forms an irregular margin, but this irregular portion may be an artifact of preservation. The left coronoid contact with the surangular is gently curved (Figure 4a). Only a small portion of right coronoid contact is visible (Figure 4b) and is straight but this is due to poor preservation

Coronoid: Left coronoid is complete, visible only its external contour (Figure 4a). Dorsal margin is concave with a well-developed posterior process, protruding $1.5 \mathrm{~cm}$ at a moderate angle. Right coronoid (Figure $4 b$ ) is compressed between surangular and prefrontal-jugal.

Jugal: The jugals are broken and the only visible part is a fragment of the horizontal bar located below the orbit (Figures 4a-b). As the "L" shaped vertex is not visible, it is not possible to define if posteroventral process on the jugal is well-developed. A small fragment of left jugal is embedded in matrix between coronoid and parietal (Figure $4 \mathrm{~b}$ ), with other bones missing.

Quadrate: The right quadrate is poorly preserved (Figures $3 \mathrm{~b}$ and $4 \mathrm{~b}$ ); it is embedded in rock with a matrix filling the skull, although its outline is still visible. The infrastapedial process is short, rounded and poorly developed; the tympanic rim and suprastapedial processes are eroded.

\section{Discussion and Conclusions}

Coniacian through the Maastrichtian are reasonably well known; however, Turonian mosasaurs are scarce, which creates a gap in the knowledge of the evolutionary history of the group (Polcyn et al., 2008). The relationships of the new specimen were analyzed by comparative paleontology. First, halisaurines and plioplatecarpines were excluded due to the lack of a pronounced rostral process. Clidastes does possess a short rostrum, but is different in the details and more "V" shaped. Additionally, the shape of the frontal, the dental formula, and maxilla-premaxilla suture, excluded these taxa. Lack of a strongly buttressed coronoid process excludes all other derived mosasaurines.

The SGM-M1 specimen shares a number of features with Tylosaurus, such as the shield-like frontal, dental formula and elongate and rounded predental rostrum. The new material differs in proportion of the predental rostrum and appears to be shorter than either $T$. proriger or T. nepaeolicus. Additionally, the external nares begin at approximately the $4^{\text {th }}$ maxillary tooth in T. proriger and $T$. nepaeolicus, but it is more anterior in our specimen. Absence of a developed infrastapedial process of the quadrate and the internarial bar, which is triangular in cross-section, places the specimen close to T. kansasensis (sensu Everhart, 2005a) but a significant difference is the absence of the central ridge on the frontal; however, this absence may be due to erosion and/or poor preservation. Thus, using anatomical features of SGM-M1 in comparison with other specimens, it could be determined that it belongs to the taxon Tylosaurus Marsh, 1872, with significant affinities with Tylosaurus kansasensis Everhart 2005b. Due to poor preservation and the possibility that the postcranial skeleton remains in the site, a more detailed search and a stratigraphic, micropaleontologic analysis, and a proper restoration of the specimen is needed.

\section{Acknowledgments}

The author wishes to express his acknowledgment to the staff of the Oficina Regional Chihuahua (ORC) of the Servicio Geológico Mexicano (SGM), that allowed the discovery of the first mosasaur skull from Chihuahua, Mexico: José Luis Bustos, Regional Manager; Olimpia Ramos, who is in charge of Centro de Documentación de Ciencias de la Tierra (CEDOCIT) Chihuahua and Michael Polcyn from the Southern Methodist University, for providing me with necessary literature and for his extensive revision of this work. Also, thanks to Héctor Rivera-Sylva, from the Museo del Desierto for his reviews. Finally, special thanks to the Subgerencia de Minerales Energéticos team, since the finding was possible thanks to the time and resources spent in this area.

Additional thanks to Mr. Mario Torres, co-discoverer of the specimen and René Hernández, whose efforts to promote paleontology in Chihuahua has inspired this work.

\section{References}

Antunes, M.T., 1964, O neocretácico e o cenozóico do litoral de Angola: Junta de Investigações do Ultramar, Lisboa, 254 p.

Bardet, N., Pereda Suberbiola, X., Jalil, N.E., 2003, A new mosasauroid (Squamata) from the Late Cretaceous (Turonian) of Morocco: Comptes Rendus Palevol, 2, 607-616. 
Bell, G.L. Jr., 1995, Middle Turonian (Cretaceous) mosasauroids from Big Bend National Park, Texas, in Santucci, V.L., McClelland, L. (eds.), National Park Service Paleontological Research, Technical Report NPS/NRP01NRTR-95/16: United States Department of the Interior, National Park Service, Denver, Colorado, $118 \mathrm{p}$.

Bell, G.L.Jr., 1997a, A phylogenetic revision of North American and Adriatic Mosasauroidea, in Callaway, J.M., Nicholls, E.L. (eds.), Ancient Marine Reptiles: San Diego, Academic Press, 293-332.

Bell, G.L.Jr., 1997b, Mosasauridae. Introduction, in Callaway, J.M., Nicholls, E.L. (eds.), Ancient Marine Reptiles: San Diego, Academic Press, 281-292.

Bell, G.L.Jr., Polcyn, M.J., 2005, Dallasaurus turneri, a new primitive mosasauroid from the middle Turonian of Texas and comments on the polyphyly of Mosasauridae (Squamata), in Schulp, A.S., Jagt, J.W.M. (eds.), Proceedings of the First Mosasaur Meeting, Netherlands Journal of Geosciences, 84, 174-194.

Buchy, M.C., 2007, Mesozoic marine reptiles from north-east Mexico: Description, systematics, assemblages and paleobiogeography: Karlsruhe, Germany, disertación doctoral, 98 p.

Buchy, M.C., Smith, K.T., Frey, E., Stinnesbeck, W., González-González, A.H., Ifrim, C., López-Olivas, J.G., Porras-Muzquiz, H., 2005, Annotated catalog of marine Squamata (Reptilia) from the Upper Cretaceous of Northeastern Mexico: Netherlands Journal of Geosciences, 84(3), 195-205.

Buchy, M.C., Frey, E., Stinnesbeck, W., López-Olivas, J.G., 2007, Cranial anatomy of a Maastrichtian (Upper Cretaceous) mosasaur (Squamata, Mosasauridae) from north-east Mexico: Revista Mexicana de Ciencias Geológicas, 24(1), 89-103.

Burrows, R.H., 1910, Geology of northern Mexico: Boletín de la Sociedad Geológica Mexicana, 7, 85-103.

Cabrera, F., Narváez, G., Chávez, J.M., Alcántara, J., Gómez, F., 1984, Exploración carbonífera en la Cuenca de Ojinaga, Chihuahua: Comisión Federal de Electricidad, Informe inédito, 45, 20 p.

Caldwell, M.W., 1999, Squamate phylogeny and the relationships of snakes and mosasauroids: Zoological Journal of the Linnean Society, 125, 115-147.

Caldwell, M.W., Carroll, R.L., Kaiser, H., 1995, The pectoral girdle and forelimb of Carsosaurus marchetessi (Aigialosauridae), with a preliminary phylogenetic analysis of mosasauroids and varanoids: Journal of Vertebrate Paleontology, 15, 516-531.

Cantú-Chapa, A., 1993, Sedimentation and tectonic subsidence during the Albian-Cenomanian in the Chihuahua Basin, Mexico, in Simo, J.A.T., Scott, R.W., Masse, J.-P. (eds.), Cretaceous carbonate platforms: American Association of Petroleum Geologists Memoir, $56,61-70$.

Castillo-Madrid, A., 1982, Reconocimiento geológico de una porción de los estados de Chihuahua y Coahuila: México, Distrito Federal, Universidad Nacional Autónoma de México, tesis profesional, $160 \mathrm{p}$.

De Braga, M., Carroll, R.L., 1993, The origin of mosasaurus as a model of macroevolutionary patterns and processes: Evolutionary Biology, $27,245-322$.

Everhart, M.J., 2005a, Rapid evolution, diversification and distribution of mosasaurs (Reptilia; Squamata) prior to the K-T Boundary: Tate 2005, $11^{\text {th }}$ Annual Symposium in Paleontology and Geology, Casper, WY, 16-27.

Everhart, M.J., 2005b, Tylosaurus kansasensis, a new species of tylosaurine (Squamata; Mosasauridae) from the Niobrara Chalk of western Kansas, USA: Netherlands Journal of Geoscience / Geologie en Mijnbouw, 84(3), 231-240.

Gervais, P., 1853, Observations relatives aux reptiles fossils de France: Comptes Rendus de l'Académie des Sciences de Paris, 36, 374377; 470-474.

Grigor'ev, D.V., Averianov, A.O., Arkhangelsk, M.S., Pervushov, E.M., Zozyrev, N.Y., 2009, A mosasaur from the Cenomanian of Russia: Paleontological Journal, 43(3), 311-317.

Haenggi, W.T., 2002, Tectonic history of the Chihuahua Trough, Mexico and adjacent USA, Part II: Mesozoic and Cenozoic: Boletín de la Sociedad Geológica Mexicana, 55(1), 38-94.

Lee, M.S.Y., 1997, Phylogeny of varanoid lizards and the affinities of snakes: Philosophical Transactions of the Royal Society of London, Series B: Biological Sciences, 352, 53-91.

Lee, M.S.Y., Caldwell, M.W., 2000, Adriosaurus and the affinities of mosasaurus, dolichosaurus, and snakes: Journal of Paleontology, $75,915-937$

Marsh, O.C., 1872, On the structure of the skull and limbs in mosasauroid reptiles, with descriptions of new genera and species: American Journal of Sciences, $3^{\text {rd }}$ ser., 3(18), 448-464.

McBride, E.F., Caffey, K.C., 1979, Geologic Report on Upper Cretaceous Coal Bearing Rocks, Río Escondido Basin, Coahuila, Mexico: Boletín de la Sociedad Geológica Mexicana, 40(1-2), 21-47.

McDowell, S.B., Bogert, C.M., 1954, The systematic position of Lanthanotus and the affinities of anguinomorphan lizards: Bulletin of American Museum of Natural History, 105, 1-42.

Mehl, M.G., 1930, A new genus of mosasaurs from Mexico, and notes on the pelvic girdle of Platecarpus: Denison University Bulletin, Journal of the Scientific Laboratories, 29(10), 383-400.

Mena-Escobar, V.A., 1994, Paleogeografía del Mesozoico en la porción centro-oriental del estado de Chihuahua: Chihuahua, Chihuahua, Universidad Autónoma de Chihuahua, tesis de licenciatura, $110 \mathrm{p}$.

Monreal, R., 1987, Regional stratigraphic studies in the Lower Cretaceous of Eastern Chihuahua, Mexico: Linares, Nuevo León, México, Universidad Autónoma de Nuevo León, Actas de la Facultad de Ciencias de la Tierra, 2, 12.

Muehlberger, W.R., 1992, Tectonic map of North America: a user's guide: American Association of Petroleum Geologists, $14 \mathrm{p}$.

Oppel, M., 1811, Die Ordnungen, Familien und Gattungen der Reptilien als Prodom einer Naturgeschichte Derselben: München, Deutschland, Joseph Lindauer, xii, 86.

Páramo, M.E., 1994, Posición sistemática de un reptil marino con base en los restos fosiles encontrados en capas del Cretácico Superior en Yaguara (Huila): Revista de la Academia Colombiana de Ciencias Exactas, Físicas y Naturales, 19, 63-80.

Páramo, M.E., 2000, Yaguarasaurus columbianus (Reptila, Mosasauridae), a primitive mosasaur from the Turonian (Upper Cretaceous) of Colombia: Historical Biology, 14, 121-131.

Petróleos Mexicanos, 1982, Informe geológico del Prospecto Camargo NEM-1854, Estado de Chihuahua: Superintendencia General de Distritos de Exploración, Zona Noreste, Distrito Chihuahua, 111 p.

Petróleos Mexicanos, 1983, Informe geológico del prospecto Candelaria NEM-1889. Detalle estructural, Estado de Chihuahua: Superintendencia General de Distritos de Exploración, Zona Noreste, Distrito Chihuahua, $133 \mathrm{p}$.

Polcyn, M.J., Bell, G.L., 2005, Russellosaurus coheni n. gen., n. sp., a 92 million-year-old mosasaur from Texas (USA), and the definition of the parafamily Russellosaurina, in Schulp, A.S., Jagt, J.W.M. (eds.), Proceedings of the First Mosasaur Meeting, Netherlands Journal of Geosciences, 84, 321-333.

Polcyn, M.J., Tchernov, E., Jacobs, L.L., 1999, The Cretaceous biogeography of the Eastern Mediterranean with a description of a new basal mosasauroid from 'Ein Yabrud, Israel, in Tomida, Y., Rich, T.H., Vickers-Rich, P. (eds.), Proceedings of the Second Gondwanan Dinosaur Symposium, National Science Museum Monographs, 15, 259-290.

Polcyn, M.J., Bell, G.L.Jr., Shimada, K., Everhart, M.J., 2008, The oldest North American mosasaurs (Squamata: Mosasauridae) from the Turonian (Upper Cretaceous) of Kansas and Texas with comments on the radiations of major mosasaur clades: Proceedings of the Second Mosasaur Meeting, Hays, Kansas, Fort Hays State University, Fort Hays Studies, 137-155.

Russell, D.A., 1967, Systematics and morphology of American mosasaurs: Bulletin of the Peabody Museum of Natural History, Yale University, 23, $237 \mathrm{p}$.

Sageman, B.B., Arthur, M.A., 1994, Early Turonian paleogeographic/ Paleobathymetric map, Western Interior, United States, in Caputo, M.V., Peterson, J.A., Franczyk, K.J. (eds.), Mezosoic Systems of the Rocky Mountains Region, USA: Society of Economic Paleontologists and Mineralogists, Rocky Mountain Section, $457-470$ 
Slingerland, R., Kump, L.R., Arthur, M.A., Fawcett, P.J., Sageman, B.B., Barron, E.J., 1996, Estuarine circulation in the Turonian Western Interior seaway of North America: Geological Society of America Bulletin, 108(7), 941-952.

Vidal, N., Hedges, S.B., 2004, Molecular evidence for a terrestrial origin of snakes: Biology Letters, 271, 226-229.

Vivar, G., 1925, Informe preliminar sobre el estudio geológico petrolero de la región de Ojinaga, Estado de Chihuahua: Departamento de Exploraciones y Estudios Geológicos, Folletos de Divulgación, 16, 3-12.

Willingston, S.W., 1897, On the extremities of Tylosaurus: Kansas University Quarterly, 6, 99-102.
Wolleben, J.A., 1965, Nomenclatura Litoestratigráfica de las unidades del Cretácico Superior en el oeste de Texas y noreste de Chihuahua: Boletín de la Sociedad Geológica Mexicana, 28(2), 65-74.

Wolleben, J.A., 1966, Biostratigraphy of the Ojinaga and San Carlos Formations of west Texas and Northeastern Chihuahua: Austin, Texas, University of Texas at Austin, disertación doctoral, 63 p.

Manuscript received: April 11, 2012.

Corrected manuscript received: September 13, 2012.

Manuscript accepted: September 20, 2012. 